\title{
DISSIDENT THOUGHT: SYSTEMS OF REPRESSION, NETWORKS OF HOPE
}

\author{
MICHAEL A. PETERS \\ mpeters@waikato.ac.nz \\ University of Waikato; \\ University of Illinois at Urbana-Champaign
}

\begin{abstract}
In this essay I examine the figure of dissident thought in the contexts of philosophical, jurisprudential and political thought. I connect dissidence to the concept of dissent and its linguistic cognates including "disagreement" and "opposition," but also the logic of negation in order to examine dissent as a condition of discourse. In the second and third sections I argue for dissent as a philosophy of non-agreement and review a theory of dissent in law. Finally, I speculate on the history of dissent and dissidence from local contexts to its first wave of global protest with the development of new social movements and the counter-culture of the 1960s and 1970s in order to postulate the changed conditions of dissent in a global, digital, mediatized world. In a postscript I ask whether there are a set of counter-conducts (Davidson, 2011) or counter-practices that can encourage a second wave of global protest, new forms of civic engagement and disobedience.
\end{abstract}

Keywords: dissidence; dissent; disagreement; opposition; negation; disobedience

How to cite: Peters, Michael A. (2016), "Dissident Thought: Systems of Repression, Networks of Hope," Contemporary Readings in Law and Social Justice 8(1): 20-36.

Received 9 May $2015 \cdot$ Received in revised form 17 July 2015

Accepted 17 July $2015 \cdot$ Available online 1 October 2015

Each society has its regime of truth, its 'general politics' of truth: that is, the type of discourse which it accepts and makes function as true; the mechanisms and instances which enable one to distinguish true and false statements, the means by which each is sanctioned; the techniques and procedures accorded value in the acquisition of truth; the status of those who are charged with saying what counts as true. --Michel Foucault (1980) Power/Knowledge: Selected Interviews and Other Writings, 1972-1977. New York, Pantheon, p. 131.

\section{Introduction: Dissent and Negation as a Condition of Discourse}

Everywhere the structures of repression of the dominant group against minorities, of racial, sexual and gender violence, of state totalitarianism 
against the citizen, engender sparks of dissidence that leads to a person, movement, literature, discourse or a form of scholarship that actively challenges an established doctrine, policy, law or institution to call out against unlawful violations of free speech and "human rights." Dissident thought is that which takes place against conformism and consensus in the name of the good of society. It is a critical principle of science, politics and discourse. It may be an underground activity that exposes the secrets and the contradictions of governments and subjects fellow citizens to moral triage in opposing the unjust, often resulting in hardship, punishment, exile and imprisonment.

The anthropology of dissidence can both theorize and document the struggles on the ground in totalitarian Soviet Russia, East Europe or China or against the cultural imperialism of the West through the diverse activities of politics, theatre, literature or poetry. It can also reflect on the nature of dissident thought as a form of public discourse and academic scholarship that is the consequence of outspoken public intellectuals who through their practice dissent and refuse the brutal and arbitrary application of power. Globalization has given birth to its own geographical and historical forms of protest, against "free trade," against "austerity," against tyrannical dictatorships, against finance capitalism and the greed of Wall St that led to the Global Financial Crisis. These contemporary protests - the Occupy movement, the Arab Spring, anti-capitalist rallies, anti-globalization mobilizations - have learned from and utilized new forms of protest and discourse of the first wave (the free speech and student movements, the peace movement, Black civil rights and later the anti-Apartheid movement, the feminist and gay movements) to broaden the politics of nonviolent protest to create imaginative public pedagogies (McKenna \& Darder, 2011).

Dissident thought has a kinship relationship with the ecology of concepts that proceed from the concepts of dissent and the very possibility of disagreement as an inherent aspect of discourse. It has taken many different forms in relation to discourse thought and action, and encompassed and cultivated political norms associated with freedom of speech that allows the expression of opposition, protest, revolt, and the expression of anti-establishment thought that takes the form of civil disobedience, non-violent protest and sometimes revolutionary activity. Often this opposition has taken the form of the metaphysics of negation brought back to life as an operating principle by Hegel but seen by some to be an intrinsic aspect of being and communication. Daniel Dahlstrom (2010) in his Presidential Address to the Metaphysical Society of America, suggests

Negation is something that we do. It is typically a judgment that we make, a judgment that something is not the case, and it usually - albeit by no means exclusively - takes the form of a statement... Negations ... are commonplace, in our lives and in our grammar, 
and they may well be a distinctive feature of human communication. Almost two decades ago Jon Barwise made the observation: 'All human languages contain one or more mechanisms of a negative character; no animal communication does' (p. 247, my italics).

In reference to Wittgenstein he takes up the matter of the constitutive importance of negation in logic, in determining truth, and in the very possibility of human thinking:

Consider how Wittgenstein, with the Sheffer stroke, introduced a negation operation to generate all truth functions. Whether one analyzes knowledge claims as suitably justified or as reliable true beliefs, it hardly suffices to show that someone believes what is the case; for both epistemological theories, it must be shown that either the reasons an alleged knower has for his true belief or the behavior he exhibits rule out beliefs to the contrary. Thus, negation appears to be a primitive element of our processes of thinking and knowing anything (p. 248). ${ }^{1}$

Dissent is a fundamental element of discourse and of discursive practice. In the history of discourse there has always been a crucial role for dissidence and contestation even with the most long-standing and sedimentary discourses in theology, philosophy and the law. Discourse always contains an element of openness that allows for new interpretations to challenge and destabilize old established views to leave room for transformation and normative change in our linguistic habits and discursive practices. This transformation bought about by dissent takes place against the consensus and agreement in practice that characterize the conceptual background of our discursive practices. Our linguistic practices, as Wittgenstein $(1953 ; 1969)$ made clear in Philosophical Investigations and On Certainty are cultural practices (in a deep sense of agreement in practice) and normative, embedded in rule-following activity that is always open to change and to contestation. These rules are revisable and capable of transformation where dissidence has an important role to play.

José Medina (2010) finds this interpretation in the thinking behind Wittgenstein's rule-following argument and his account of language:

our agreement in language should be thought of as historically extended and as remaining always open to challenges and transformations. And the open and changeable nature of our background consensus does affect the normativity of our practices: its fallibility, its lack of finality. Our normative assessments are never final and unrevisable. The correctness of our linguistic actions can always be challenged; our moves in language-games can always be normatively assessed in different ways. This openness to contestation is grounded in the openness to correction of our normative agency. Our language-games are not composed of moves whose correctness can be guaranteed once and for all; they are not activ- 
ities that can be exempted from critical scrutiny. In other words, language-games are not self-justifying activities with absolute normative autonomy (p. 8).

Dissent and "dissidence," defined here as a form of thought that challenges the status quo, are necessary elements in discursive change; they represent principles of historical dynamism in the expression of thought that represents both the new and original without which the orders of discourse would be self-stultifying. ${ }^{2}$

The term dissidence is most often associated with Russian, Central and East European movements opposing the regime in the Soviet Union, beginning in the 1960s and culminating, perhaps, in the statement by Vaclav Havel (1985: 23):

[Dissent] is a natural and inevitable consequence of the present historical phase of the [Communist] system it is haunting. It was born at a time, when this system, for a thousand reasons, can no longer base itself on the unadulterated, brutal, and arbitrary application of power, eliminating all expressions of nonconformity. What is more, the system has become so ossified politically that there is practically no way for such nonconformity to be implemented within its official structures. ${ }^{3}$

Dissent is not confined to an historical era or to the nature of totalitarian or closed political systems. It is a universal feature of human life, thinking and discourse that provides the first principle of criticism realized in a formal sense by Kant but constitutive of the negative - the "No" - and logically related to the affirmative - the "Yes" - that drives the system of discourse and creates the regime of true statements and the possibility of opinion.

\section{Dissent as a Philosophy of Non-Agreement}

Dissent is the main principle of opposition classically conceived, a philosophy of non-agreement that makes opposition to a prevailing idea, policy or institution central to public and political discourse. Dissent is structurally or formally enabled in political systems through opposition parties often accompanied by social or political activism and forms of civil disobedience organized by those called "dissidents," where it is not entirely suppressed and driven underground by repressive regimes. Dissent in this sense as a principle of public discourse in a democracy rests on and is dependent on freedom of thought framed by freedom of speech that enshrines the possibility of dissent as a useful working political methodology that enable the expression of dissenting ideas especially from minorities against a majority consensus. The coercive elimination of dissent, the active silencing of the 
minority opposition is the apparatus of the police state that tries to preserve a one-party mythological unity that leads to propaganda, manipulation of news media, and the rigid control of official voices. The abolition of dissent is institutionalized in a monological pedagogy that cultivates the production of pupils as ideology-receptacles. Dialogical pedagogy, by contrast, rests on the possibility and encouragement of disagreement. Dissent is the first stage of criticism and a necessary adjunct of critique and other public forms of discourse that challenge existing authorities, deviate from the official narratives, proposing their counter-narratives and releasing subjugated knowledges and identities.

Dissent is also the living force that enables dissident thought to take the form of criticism beginning as textual commentary and leading to interpretation that opposes or takes its departure from established thought. In the modern sense criticism is born with the three Kantian critiques as inquiries into the very possibility of knowledge.

The Kantian critique is different from the classic Hegelian critique which issues from nay-saying, from the contradiction and the force of negation that define the dialectic. Judith Butler (2009) usefully defines the meanings of critique for Kant:

In the Critique of Pure Reason, Kant lays out several meanings and functions of critique, including the dethroning of metaphysics, the overcoming of what he called the reign of tedium (a perpetual altercation between skepticism and dogmatism), an effort to supply sufficient grounding for the sciences, the attempt to establish a way of deriving knowledge claims from a priori principles, and a way of distinguishing such claims from empirical ones as well as speculative ones. Critique is also described as a kind of revolution, what he calls a revolution at the level of procedure, a progressive path for science, a way of enforcing rightful claims, of protecting the public against harmful doctrines (especially those that involve contradiction, groping [Herumtappen], and excess), and a way of resisting popularity and yet serving the public (p. 777).

Most importantly, as Butler explains Kant is also highlighting a question with regard to the mode of self-legitimation of any project of knowledge: "in what way?" and "by what right?" (p. 778). Kant's critique is an inquiry into the very possibility of knowledge and the capacity of human reason to be able to undertake it.

For Hegel, by contrast, the power of "negation" constitutes the dynamic aspect of the dialectic as it is only through "negativity" that we can move beyond static or habitual thought to dissolve it and then move on toward "the whole". The power of negation drives the dialectical process by revealing contradictions within any category or identity although Hegel's notion of the 
dialectic does not stand for simple opposition. He challenges the notion of self-identity given classically in identity theory as $\mathrm{A}=\mathrm{A}$. By contrast Hegel talks of a set of relations including difference, opposition, reflection or relation. On his logic through the power of negation categories are sometimes shown to be self-contradictory. His Science of Logic (1817) reveals three different kinds of contradiction: Being/Nothing (Quality/Quantity); in the division of Essence, Inner/Outer where to define one is at the same time to define the Other; and with Concept we have examples where component parts are conceptually interrelated such as with the concept of identity comprised of Universality and Particularity. Negation is the force that drives the logic of the dialectic in its simple organic form: thesis, antithesis, synthesis. ${ }^{4}$

Marx admired the Hegelian dialectic while criticizing the system and recommending it as the first modern political economy:

The outstanding achievement of Hegel's Phänomenologie and of its final outcome, the dialectic of negativity as the moving and generating principle, is thus first that Hegel conceives the selfcreation of man as a process, conceives objectification as loss of the object, as alienation and as transcendence of this alienation; that he thus grasps the essence of labour and comprehends objective man - true, because real man - as the outcome of man's own labour. ${ }^{5}$

The nihil of Russian nihilism is also a form of negation. It is only one species of nihilism that dates back to the Greek philosopher Gorgias where negation was cultivated as an expression of meaninglessness. Typically nihilism takes a variety of forms: metaphysical (no objects), epistemological (only skepticism), moral (no morality), existential (no intrinsic value) or political (no authority). Russian nihilism was a movement in the 1860 s that rejected all political authority and sanction violence as a means of political change.

The term was used by Friedrich Jacobi to characterize the rationalism of Kant's critique whose idealism fell into nihilism according to Jacobi, and it was Ivan Turgenev who popularized the term in Fathers and Sons (1862), soon after adopted by the Russian movement. Nietzsche's decisive reading becoming explicit in his Notebooks saw the death of God as an event that no longer guaranteed the meaning or purpose of life. Both his work and Heidegger's interpretation of it in "The History of European Nihilism" the fourth book of his monumental Nietzsche emphasizes the Will to Power as the expression of the death of God and the devaluation of the highest values. It is an interpretation that allows Heidegger to talk of Western metaphysics as essential nihilistic in that is has forgotten Being (Sein) mistaking it for a Being (Seiende). 
This reading view the history of Western thought as Western metaphysics as the destruction of Being. The "no," the "negation" inherent in this version of the nihil is a powerful source of dissent and of dissident thought disrupting the traditional hierarchy of values, challenging the self-aggrandizing mythology used to buttress the timeless truths of the West, and through this negation opening up the West for an alternative set of futures. Nietzsche and Heidegger's interpretation set out a new discursive game in philosophy that can talk of creation within a nonfoundational universe and it acts as a source of inspiration for Sartre, Deleuze, Derrida, Foucault, Vattimo, Rorty, Severino and many others. ${ }^{6}$

Nietzsche's work has inspired various accounts of nonfoundational thought and ethics in characterizations like Vattimo's "weak thought." "Negative thought" is a movement founded by Massimo Cacciari to identify the failures of traditional logic to explicate the problems of modernity. Caccciari in Krisis (1976) and Negative Thinking and Rationalization (1977) finds his locus in Nietzsche, Wittgenstein and Heidegger to confirm the end of classical rationality and a refounding in "negative thinking." Matteo Mandarini (2009: 38) argues Cacciari's Krisis

\begin{abstract}
was central to the development of a number of subsequent tendencies in Italian philosophy, political theory and political practice, is attested to by its influence on the development of 'weak thought' (pensiero debole) and, more importantly, on the notion of the 'autonomy of the political' as adopted by some of the leading intellectuals of the Italian Communist Party...
\end{abstract}

For me the most definitive of the French Nietzsche revival was Deleuze whose book Nietzsche and Philosophy (1962) paved the way for a concept of "dissident thought," together with Foucault's materialization of discourse and Roland Barthes' nouvelle critique. Each of these proposed useful accounts of "dissident thought" that broadened and diversified the practice, ethos and institution of criticism. In each case the formal oppositional viewpoint is amplified and given new strength and direction.

Barthes argues that literary criticism if it is to function as (nouvelle) critique and as the new master discourse of the academy, it must transcend its tradition role as simply making a judgment about literature in relation to its norms and conventions to criticize the language and the language games of the institution beyond reinforcing the academic doxa and the status quo of the institution. The rise of cultural studies starts as a consequence of the shutting down of conventional academic discourse as a result of the market agenda of the corporate university. Some would argue that the attempt to radicalized institutional critique has long failed and the abdication of cultural studies has left the university with no critical force to subject neoliberal power to analysis or effective critique. In this context "dissident thought" 
differs from the Enlightenment emphasis on consensus but looks to dissensus. It is not tuned to a convergence but exists only as a divergence and diversity of thought. ${ }^{7}$

\section{A Theory of Dissent in Jurisprudence}

The structural role of dissent and disagreement in discourse is also recognized in legal discourse and the making of the law. Thomas Morawetz (1992) provides a Wittgensteinian understanding of the possibility of "disagreement" in jurisprudence. Writing in 1992 Morawetz explains the move from the old foundationalist jurisprudence motivated by the possibility of achieving a consensus on public values and social progress to a new skeptical and antifoundationalist jurisprudence that has fallen under the spell of philosophical arguments about language, truth and meaning, originating in Wittgenstein and played out by Richard Rorty in a rebuttal of "knowledge as accurate representation." The transition to the new jurisprudence takes place through three "destabilization arguments:" the moral argument destabilizes liberalism faith in public values through an assault on the objectivity of rights; "the conceptual argument impeaches ideological neutrality by uncovering multiple narratives and alternative voices that coexist in time and space and offer irreconcilable ways of ordering experience. Finally, the semantic argument undercuts communication with deconstructive arguments that characterize meaning as hearer-determined" (p. 376). After an exhaustive review of the arguments for law as a deliberative practice he concludes:

If Wittgenstein is right, and if philosophy 'leaves everything as it
is,' then describing law as a deliberative practice can be neither
conservative nor radical. The law itself, the deliberative practice
that is law, will be conservative if the society is homogeneous or
successfully repressive, if new voices and ways of thinking remain
unrepresented. The law will be radical if society is heterogeneous
and new ways of justifying and conceiving aims are continually
given legal expression. The law will, furthermore, be liberal in Mill's
sense whenever it is open to new ways of thinking, whenever
judges recognize that their ways of reasoning and justifying, i.e.
their stake, do not necessarily have hegemony (p. 456).

In the age of globalization, the concept of international law throws up a new set of problems about disagreement and specifically what some scholars regard as incommensurable problems with different conceptions of law such as the radical difference between Western and Shar'ia law. The ground shifts when considering law and opposition within the US.

M. Todd Henderson charts the opposition to dissent by John Roberts as Chief Justice of the US Supreme Court who sees it as weakening the Court 
by exposing internal divisions and also thus also weakening the Rule of Law. The hostility to dissent has a history in the Court but some justices, "most famously Chief Justice Stone and Justice William Brennan, dissent is considered a healthy, and even necessary, practice that improves the way in which law is made" (p. 2.). As Henderson goes on to explain:

Their counter-position rests in part on two ideas: first, dissents communicate legal theories to other justices, lawyers and political actors, state courts, and future justices, and have sometimes turned into good law later on as a result of this; and second, dissents are essential to reveal the deliberative nature of the Court, which in turn improves its institutional authority and legitimacy within American governance (p. 2).

He argues that "the elimination of dissents would not move the Court in the direction of a more efficient or perfected state of discourse" (p. 2) and referring to Foucault on truth and power, "Style reflects power, and the Court's choice of style is about the Court's power" (p. 2). Henderson usefully hypothesizes a theory of dissent beginning with Foucault's assertion "the characteristic of our Western societies [is] that the language of power is law"

But the law does much more than this. Law constructs much of modern discourse, since it authorizes some to speak and some views to be taken seriously, while others are marginalized, derided, excluded, or even prohibited. The law creates discourse that affects all citizens through the creation of 'episteme' - historically enduring discursive regularities that act as perception grids within which thought, communication, and action can occur (p. 5).

In examining the relations between discourse, power and truth in the making of law Henderson maintains "Historically the word 'truth' was synonymous with 'fact' or 'actuality"' (p. 7) and he goes on to argue:

Law is one of the most powerful discourses in that it claims not only to reveal the truth, like science, but also to consecrate it as the Law, the sole source of legitimate physical power. In this context, an appellate opinion is a source of truth and a representation of power, not so much as an evaluation of the 'facts' of a particular case, but rather what 'facts' are acceptable within the legal grid that the court creates (ibid).

In the context of a brief history of dissent he reviews three models of ways in which courts has delivered their judgments in the course of Anglo-American jurisprudence: the English model where the seriatim delivery of the judgment of each judge individually; delivering an "opinion of the court;" and the modern US practice where judges decide individually whether to "write separately." His history demonstrates that "the history of debates about the 
opinion delivery practices of Anglo-American courts has been about court power" (p. 48) mostly about restricting its power.

\section{Dissidence and Dissent in Political Life: The 1960s Counterculture}

The history of dissident thought in the West and the meaning of opposition was part of the dialectics of the Cold War and the organized radicalism that took place in the 1950s to formulate an anti-Stalinist Left, a living embodiment of dissent based on the power of critique. ${ }^{8}$ Much of the organized radicalism appeared under the acceptable face of democratic socialism that had imbibed the principles of dissent from various forms of Western Marxism. ${ }^{9}$

The 1960s counterculture was not confined to the US or the West. Its radical underpinnings were in decolonization movements initiated by Gandhi's philosophy of non-violence, the work of Fanon, Césaire, and other "postcolonial" luminaries who sparked movements against imperialism. There were many peasant uprisings in the medieval and eras, ${ }^{10}$ often part of broader indigenous movements against the confiscation of land, racial discrimination, and new forms of colonial domination that began with first contact in the Americas and ex-European colonies and have developed substantially in the era of anti-globalization movements. ${ }^{11}$

Radical movements in the post-war that began in the US and Europe spread quickly to South America, the Eastern bloc and the Antipodes. The American civil rights movement under Martin Luther King Jr. initiated protest action to end the official segregation and disenfranchisement of AfricanAmericans, and later produced radical groups such as Black Power movement, Black Panther Party and Black Muslims. "Postcolonialism" was coming of age at least in the sense that many countries in Africa and Asia had recently received their independence and authors such as Frantz Fanon and Aimé Césaire, as well as the Harlem Renaissance poets, had been rediscovered. It was also the beginning of protest against apartheid in South Africa. In this regard we should not forget the "race riots" in Watts (34 people killed in 1966), Detroit (1967) and Cleveland. This era was also the beginning of the official recognition of multiculturalism as a policy (although actual policies did not emerge until the early1970s and first in Canada in response to the demands of the Quebecois).

The 1960s also heralded an age of mass protest against the Vietnam War and US foreign policy in the late 1960s which grew out of the 1950s "peace movement" and CND that radicalized a generation of student-youth, based mostly in universities, that eventually led to resistance to the war and the shootings at Kent State University in May 1970 (where four students were killed and many others wounded by the National Guard). In this connection, we should also note the Free Speech movement that began at Berkeley in 
1964 emphasizing student's rights to free speech and academic freedom, and protesting against a ban limiting political activities. Associated with these movements - Black and student movements - the 1960s also saw the birth of the New Left, which was an imported rhetoric that had little basis in the labor movement or, indeed, Marxist politics on the ground but, nevertheless inspired student protest and linked the US with movements elsewhere developing a significant global civic awareness.

Second-wave feminism took root and initiated action to improve women's rights and gender equality. This period in feminism saw the development of radical feminist theory that theorized patriarchy and held CR groups among women across class divisions to focus not only on economic equality, sexual harassment, maternity leave and affirmative action but also greater control over women's health and sexuality, including "reproduction politics," "prochoice," radical lesbianism and sexual experimentation. The women's movement coincided with the birth of the gay rights movement that sought greater equality for lesbians, gays, bisexuals and transgenders. The Stonewall riots in New York in 1969, involving violent conflict between police and homosexuals in a Greenwich Village gay bar, is generally taken as the beginning of modern gay rights, leading to the formation of the Gay Liberation Front, gay pride celebrations and marches, and a new era of sexual politics that questioned gender identity, "normalcy" of sexual orientation and the extent of societal homophobia.

Informing these movements and being shaped by them, the 1960s became synonymous with emergent, novel and experimental cultural forms, especially revolving popular music and the rapid growth of youth subcultures. This "alternative culture" was to some extent the inheritor of Black music, 1950s experimentation, the Beat Generation, and the associated perceived "teenage crises" and "moral panics." Musically, the era is perhaps often symbolized by Bob Dylan's "The Times They Are A-changin'," which crystallized the political and ethical break with the mainstream. Dylan, drawing on the American folk tradition symbolized by Woody Guthrie, provided a new lyricism combining poetic and philosophical elements that commented on what was happening and challenged the political status quo.

In a strong sense this first global movement of dissidence based on the export of countercultural youth styles around the globe also set the condition and tone for the second and third global movements: the anti-capitalist and anti-globalization struggles of 1990s and 2000s, a kind of rainbow coalition with a strong ecology and sustainability orientation, ${ }^{12}$ and; the movement of cyberactivism that grew from the hacker cultures of the 1960s (Levy, 1984) dedicated to the principle of free information to its maturity in the work of Richard Stallman and Linus Torvalds, as intellectual leaders of the openness movement. 


\section{Postscript: Dissent in the Age of Digital Reason}

At a recent conference devoted to the history and meaning of opposition from 1968 to the present (see footnote 4), the Research Group on International Studies frames the issue in terms of the diversity of forms of protest and of historical continuity:

Globalization, post-9/11 politics and the post-2008 financial crisis have all birthed modes and histories of opposition and dissent, be they dissent from global political-economic systems or opposition to ranges of international authoritarian regimes. Contemporary dissent, however, oft-draws from forms and imaginations of earlier modes of protest, be they student protests from the late ' 60 s onward, the peace movement in the same period, the anti-nukes movement of the 1980s or the anti-Apartheid movement spanning the ' $60 \mathrm{~s}$, '70s and ' 80 s. Still, dissent takes other historical forms: individual critiques of 'actually existing' socialist systems, be they civil rights based critique from individual figures such as Sakharov or Rostropovich (or Solzhenitsyn's nationalist-culturalism), mediadriven dissent, such as the political magazine Mladina's criticisms of the Yugoslav regime in the late 1980s and early 1990s or the voices of "everyday" social actors, such as the Damas de Blanco in Cuba. In a historical period encapsulating the last decades of the Cold War and an unfolding twenty-first century, dissent and social opposition undergo and have undergone redefinition within the confines of modern and contemporary culture.

Arguably, dissent and dissidence previously local and confined to regions and repressive states developed its first wave of global protest beginning with the Peace movement in the 1950s leading to the development of new social movements and the counter-culture of the 1960s and 1970s. This was perhaps its first global expression as a culture of protest that institutionalized itself within liberal democratic orders. Yet with the changed conditions of dissent in a global, digital, mediatized world we need to ask whether there are a set of counter-conducts (after Foucault, Davidson, 2011) or counterpractices that can encourage a second wave of global protest, new forms of civic engagement and disobedience. In the age of digital reason (Peters, 2014) in what ways is resistance possible within the global mode of digital governmentality that subjects us to new horizontal and democratic forms of control where self-surveillance parallels the digital panopticon of big data systems and surveillance technologies both the State and the digital multinational corporation?

In an interview with Jordan Skinner, Frédéric Gros the editor and commentator of Foucault's works, (Skinner, 2014) makes an observation about 
the continued relevance of Foucault's work to thought and action in the digital age's universe of generalized surveillance. He comments:

Foucault's great studies of disciplinary society are useful above all because they allow us to delineate, through contrast and comparison, the digital governmentality that subjects us to new forms of control, which are less vertical, more democratic and, above all, no longer burdened by any anthropological ballast. Homo digitalis today participates in, is the primary agent of, the surveillance of himself. Digital society is becoming a form of mutualised control. We should today consider the treatment of 'big data' working with Foucault, basing ourselves on him, but seeing further than he could. Because we have gone well beyond the disciplinary age. Security's new concepts are no longer imprisoning individuals and normative consciousness, but rather traceability and algorithmic profiling. ${ }^{13}$

Gros also mentions the other great aspect of Foucault's thought that focuses on the genealogy of subjectivity and the self but without relating it to the new global digital systems that have the power to recast identity in new digital forms through the power of surveillance and through the surveillance carried out by the State in conjunction with large information utilities that increasingly profile and "personalize" individuals as market segments or niches.

In the digital age prodemocracy movements are different from those in the "1989" era in Soviet Russia and China as they are increasingly protests arising within the global surveillance global system spawning new forms of cyberactivism and civil disobedience, championed by the new cyber-dissidents like Edward Snowden and Julian Lassange adopting a human rights approach to global freedoms in the digital world. ${ }^{14}$ At the same time social media have functioned as tools for political coordination especially for youth involved in the so-called Arab Spring that igniting historically irreversible political change brought down strongman dictatorships and oppressive and corrupt one-party regimes. ${ }^{15}$ While the Arab Spring has turned to dust, consuming its indigenous form of a social democratic promise into a new series of takeovers and mass protests, it demonstrated in new form of dissidence based on cyberbased disobedience in a political arena seemingly immune to change where civil rights, especially for women, have been strongly resisted and completed denied in some cases. It also demonstrated the vulnerabilities of oppressive regimes to world information flows and new forms of citizen journalism in an increasingly interconnected world. In this new media environment dissidence often takes a digital aesthetic form so that it is appropriate to talk of new "styles" of dissidence demonstrated by Pussy Riot's civic disobedience in the Post-Soviet context (Tchermalykh, 2014). ${ }^{16}$ 
In these new forms of dissidence that increasingly define prodemocracy, ecological movements, and cyberactivism, political subjectivity depends on the global linking of autonomous cells and regional networks in transversal and rhizomic structures that favor horizontal, non-hierarchical and transspecies connections (Peters, 2013). These networks of hope are the emergent counter-practices and counter-conducts that speak truth to power in the emergent interconnected digital world that is now our home.

\section{Acknowledgement}

My thanks to Tina Besley, Michael Apple and E. Jayne White for helpful comments on earlier drafts of this paper. A version of this paper appeared in Etnografie del dissenso (The ethnographies of dissent) (2015).

\section{NOTES}

1. The Sheffer stroke (after Henry Sheffer) in propositional calculus denotes the function of negation, often expressed as "not both." In Boolean algebra it is called the NAND operation and represented by "I" or an upwards arrow " $\uparrow$," such as as $\mathrm{A} \mid \mathrm{B}, \mathrm{Dpq}$, or $\mathrm{A} \uparrow \mathrm{B})$.

2. See Terry Eagleton's (2003) popular account which is not theorized but rather a series of profiles or sketches of dissidents that embraces the widest sense of the term.

3. See Yaroslav Bilinsky's account at http://www.answers.com/topic/dissidentmovement\#ixzz3Ay2Tli8W. See also Solzhenitsyn (1985), Rubenstein (1985) and especially Aviezer (2000) on the philosophy and politics of Czech dissidence.

4. See https://www.marxists.org/reference/archive/hegel/works/hl/hlconten.htm

5. "Critique of Hegel's Philosophy" in Economic and Philosophic Manuscripts of 1844 (XXIII), https://www.marxists.org/archive/marx/works/1844/manuscripts/ hegel.htm

6. In this context it is important to acknowledge Sartre's towering contribution to forms of civil protest in France during the post-war period a form of atheistic and existential humanism that later gave way to dissident Marxism especially in The Critique of Dialectical Reason (1991).

7. See Lyotard's (1988) The Différend and Rancière's (2011) "The Thinking of Dissensus." See my "Lyotard, Nihilism and Education" (Peters, 2006).

8. The genealogy of critique is an important part of the history of negation from Kant, Hegel and Nietzsche to Sloterdijk and Spivak - as a systematic analysis of discourse and theory, involving the faculty of judgment, to examine the validity and limits of an argument, to expose its ideological underpinnings. Critique, originally a French word, indistinguishable from the concept of "criticism" is the basis for use of the term "critical" especially as evidenced in the notion of "Critical Theory" that grew up in a German context with founders of the Frankfurt School but now no longer tied exclusively to dialectical reason has a public usage broadly functioning as a disciplined form of criticism including non-dialectical forms of reasoning. 
9. See the institutional history of the American journal Dissent, founded in 1954 by Irving Howe by Maurice Isserman (2014) "Steady Work: Sixty Years of Dissent" at http://www.dissentmagazine.org/online_articles/steady-work-sixty-years-of-dissent. In this connection see also the recent conference of the Research Group on International Studies "Dissent!: Histories and Meanings of Opposition from 1968 to the Present" (January 16-17, 2014) at http://www.dissent.aau.dk/. The conference website includes the following useful orientation: "The conference seeks to reveal dissent in its ideological, social and political diversity. The conference seeks to comprehend dissent as 'owned' not by one counter-cultural or ideological position, but via broad pastiches of global movements and ideas. The conference seeks to address socio-political opposition as contextually responsive and historically diverse. Moreover, Dissent! seeks to examine dissidence in a period where late twentieth and early twenty-first centuries do not necessarily 'break' (typically around 1989), but rather provide genealogies of acts warranting comparison, narrativization, theorization and representation under the heading of "social and political opposition." This section draws on a few paragraphs from my "Leo Strauss and the Neoconservative Critique of the Liberal University: Postmodernism, Relativism and the Culture Wars" (Peters, 2008).

10. Wat Tyler's Rebellion took place in parts of England in 1381 as an example of a form of popular revolt in the medieval era, see http://en.wikipedia.org/wiki/ Popular_revolt_in_late-medieval_Europe.

11. See for instance "500 Years of Indigenous Protest" at http://www.dickshovel. com/500.html; see also http://www.democracyuprising.com/2007/04/anti-globalization-movement/ and http://www.globalissues.org/article/45/public-protests-aroundthe-world.

12. See my "Antiglobalization" and Guattari's The Three Ecologies. Globalization, http://globalization.icaap.org/content/v2.1/02_peters.html. See also Peters (2013) for an account of Guattari's transversalist conception of subjectivity as a basis for dissent and dissidence in an age ecosystems - natural, digital and social.

13. http://www.versobooks.com/blogs/1653-foucault-s-legacy-an-interview-with -frederic-gros

14. See http://www.advancinghumanrights.org/supporting-dissidents/cyberdissidents

15. See my Peters, M. A. (2011), "The Future of Muslim Youth: Interview with Linda Herrera," Policy Futures in Education 9(2): 248-257.

16. See Masha Alyokhina's Closing Statement at the FreePussyRiot website, http://freepussyriot.org/content/masha-alyokhinas-closing-statement.

\section{REFERENCES}

Butler, J. (2009), “Critique, Dissent, Disciplinarity,” at http://www.philol.msu.ru/ summer/images/stories/texts/texts12/Butler.pdf

Caccciari, M. (1976), Krisis. Saggio sulla crisi del pensiero negativo da Nietzsche a Wittgenstein. Milano: Feltrinelli.

Caccciari, M. (1977), Pensiero negativo e razionalizzazione (Negative Thinking and Rationalization). S. Croce, Venezia: Marsilio Editori. 
Dahlstrom, D. (2010), "Negation and Being," Presidential Address at the 61st annual meeting of the Metaphysical Society of America, Boston University, March 5-6, 2010, at http://www.bu.edu/philo/files/2013/09/d-Negation-and-Being.pdf

Davidson, A. I. (2011), "In Praise of Counter-Conduct," History of the Human Sciences 24(4): 25-41.

Deleuze, Gilles (1962), Nietzsche and Philosophy. Translated by Hugh Tomlinson. London and New York: Continuum.

Eagleton, T. (2003), Figures of Dissent: Critical Essays on Fish, Spivak, Žižek and Others. London: Verso.

Foucault, Michael (1980), Power/Knowledge: Selected Interviews and Other Writings, 1972-1977. New York: Pantheon

Havel, Vaclav (1985), "The Power of the Powerless," in Havel, Vaclav, et al., The Power of the Powerless: Citizens against the State in Central-Eastern Europe, John Keane (ed.). London: Hutchinson.

Heidegger, M. (1991) Nietzsche. Vols. 1-2 and 3-4. Trans. \& ed. by David Farrell Krell. New York: Harper.

Henderson, M. Todd (2007), "From Seriatim to Consensus and Back Again: A Theory of Dissent," John M. Olin Program in Law and Economics Working Paper Series: http://www.law.uchicago.edu/Lawecon/index.html

Levy, S. (1984), Hackers: Heroes of the Computer Revolution. New York: Anchor Press/Doubleday.

Lyotard, J-F (1988) The Differend: Phrases in Dispute. Trans. Georges Van Den Abbeele. Manchester: Manchester University Press. Trans. of Le Différend. Paris: Minuit, 1983.

Mandarini, M. (2009), "Beyond Nihilism: Notes Towards a Critique of LeftHeideggerianism in Italian Philosophy of the 1970s," Cosmos and History: The Journal of Natural and Social Philosophy 5(1): 37-56.

McKenna, B., and Darder, A. (eds.) (2011), "The Art of Public Pedagogies," Special issue of Policy Futures in Education, at http://www.wwwords.co.uk/pfie/content /pdfs/9/issue9_6.asp

Medina, José (2010), "Wittgenstein as a Rebel: Dissidence and Contestation in Discursive Practices," International Journal of Philosophical Studies 18(1): 1-29.

Morawetz, T. (1992), "Understanding Disagreement, the Root Issue of Jurisprudence: Applying Wittgenstein to Positivism, Critical Theory, and Judging," University of Pennsylvania Law Review 141(2): 371-456.

Peters, M. A. (2002), “Antiglobalization' and Guattari's The Three Ecologies. Globalization, http://globalization.icaap.org/content/v2.1/02_peters.html. Also in Peters, M. A., Olssen, M. and Lankshear, C. (eds.), Futures of Critical Theory: Dreams of Difference. Lanham, MD: Rowman and Littlefield, 275-288.

Peters, M. A. (2006), "Lyotard, Nihilism and Education," Studies in Philosophy and Education 25(4): 303-314.

Peters, M. A. (2008), "Leo Strauss and the Neoconservative Critique of the Liberal University: Postmodernism, Relativism and the Culture Wars," Critical Studies in Education 49(1): 11-32.

Peters, M. A. (2011), "The Future of Muslim Youth: Interview with Linda Herrera," Policy Futures in Education 9(2): 248-257. 
Peters, M. A. (2013), "Institutions, Semiotics and the Politics of Subjectivity," Geopolitics, History and International Relations 5(1): 11-26. Also in Dillet, B., Mackenzie, I. and Porter, R. (eds.), The Edinburgh Companion to Poststructuralism. Edinburgh, University of Edinburgh Press.

Peters, M. A. (2014), "The University in the Epoch of Digital Reason: Fast Knowledge in the Circuits of Cybernetic Capitalism," in Paul Gibbs, Oili-Helena Ylijoki, Carolina Guzmán-Valenzuela, and Ronald Barnett (eds.), Universities in the Time of Flux: An Exploration of Time and Temporality in University Life. London: Routledge.

Radsch, Courtney C. (2014) Digital Dissidence \& Political Change: Cyberactivism and Citizen Journalism in Egypt. Doctoral Dissertation, American University, School of International Service. December 2013, at http://papers.ssrn.com/sol3/ papers.cfm?abstract_id=2379913.

Rubenstein, Joshua (1985) Soviet Dissidents: Their Struggle for Human Rights. 2nd edn., rev. and exp. Boston, MA: Beacon Press.

Sartre, Jean-Paul (1991), Critique of Dialectical Reason Volume 1: Theory of Practical Ensembles; Volume 2: The Intelligibility of History. London: Verso.

Skinner, J. (2014), "Foucault's Legacy: An Interview with Frédéric Gros," at http:// www. versobooks.com/blogs/1653-foucault-s-legacy-an-interview-with-fredericgros

Solzhenitsyn, Aleksandr I. (1985), The Gulag Archipelago 1918-1956: An Experiment in Literary Investigation. Tr. Thomas P. Whitney (Parts I-IV) and Harry Willetts (Parts V-VII), abridged by Edward E. Ericson, Jr. New York: Harper and Row.

Tchermalykh, Nataliya (2014), "Will Pussy Riot Dance on \#Euromaidan? New Dissidence, Civic Disobedience and Cyber-Mythology in the Post-Soviet Context," Religion and Gender 4(2), at http://www.religionandgender.org/index.php /rg/article/view/9845

Tucker, Aviezer (2000), The Philosophy and Politics of Czech Dissidence from Patocka to Havel. Pittsburgh, PA: University of Pittsburg Press.

Wittgenstein, L. (1953), Philosophical Investigations. Oxford: Blackwell.

Wittgenstein, L. (1969), On Certainty. Oxford: Blackwell. 
Copyright of Contemporary Readings in Law \& Social Justice is the property of Addleton Academic Publishers and its content may not be copied or emailed to multiple sites or posted to a listserv without the copyright holder's express written permission. However, users may print, download, or email articles for individual use. 